DOI: 10.26907/2311-2042-2021-16-1-172-178

\title{
SCIENTIFIC ACTIVITIES AND LITERARY CRITICISM OF NIL YUZIEV
}

\author{
Nurfiya Marsovna Yusupova, \\ Kazan Federal University, \\ 18 Kremlyovskaya Str., Kazan, 420008, Russian Federation, \\ faikovich@mail.ru.
}

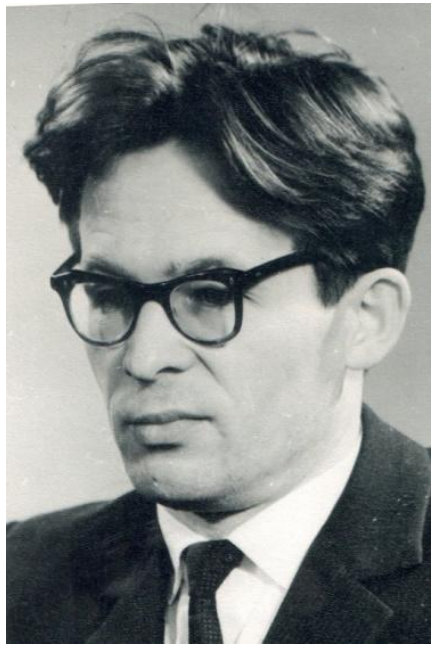

Nil Gafurovich Yuziev (1931 1996) was a linguist, Doctor of Philology, Professor, Honored Scholar of the TASSR (1981), Laureate of the G. Tukay State Prize of the Republic of Tatarstan (1974), literary critic, the author of 36 monographs and more than 300 articles. In 1958, he presented his Ph.D. thesis "Poems of Musa Jalil" and, in 1974, his Doctoral thesis "Poetics of Tatar Soviet Poetry" was completed. He taught at Kazan State University from 1960 to 1975 . He was the head of the Literature Sector at G. Ibragimov Institute of Language, Literature and History of the USSR Academy of Sciences (now - G. Ibragimov Institute of Language, Literature and Arts of the Academy of Sciences of the Republic of Tatarstan) from 1975 to 1985 . N. Yuziev was the Head of the Department of Manuscripts and Textology of G. Ibragimov Institute of Language, Literature and Arts of the Academy of Sciences of the Republic of Tatarstan from 1986 to 1996.
Нил Гафур улы Юзиев $(10.01 .1931-11.09 .1996)-$ әдәбият галиме, тәнкыйтьче, филология фәннәре докторы, профессор, ТАССРның атказанган фән эшлеклесе (1981), Татарстан Республикасының Г. Тукай исемендәге Дәүләт бүләге лауреаты (1974), 36 монография, 300дән артык мәкаләләр авторы. 1958 елда «Муса Жәлил поэмалары» темасына кандидатлык диссертациясен, 1974 елда «Татар совет поэзиясенең поэтикасы» темасына докторлык диссертациясен яклый. 1960-1975 елларда Казан дәүләт университетында педагогик һәм гыйльми эшчәнлек алып бара. 1975-1985тә СССР ФАнең Казан филиалы Г. Ибраһимов исемендәге Тел, әдәбият һәм тарих институтында (хәзер: ТР ФАнең Г. Ибраһимов исемендәге Тел, әдәбият һәм сәнгать институты) әдәбият секторы житәкчесе. 1986-1996 елларда ТР ФАнең Г. Ибраһимов исемендәге Тел, әдәбият һәм сәнгать институтында кулъязмалар һәм текстология бүлеге мөдире вазифасын башкара.
Нил Гафурович Юзиев (10.01.1931 - 11.09.1996) - ученый, критик, доктор филологических наук, профессор, заслуженный деятель науки ТАССР (1981), лауреат Государственной премии им. Г. Тукая (1974), автор 36 монографий и более 300 научных работ. В 1958 году защитил кандидатскую диссертацию на тему «Поэмы Мусы Джалиля», в 1974 году - докторскую диссертацию на тему «Поэтика татарской советской поэзии». В 1960-1975 гг. Н. Г. Юзиев вел научнопедагогическую работу в Казанском государственном университете. С 1975 по 1985 гг. - заведующий сектором литературы Института языка, литературы и истории им. Г. Ибрагимова КФАН СССР (ныне Института языка, литературы и искусств им. Г. Ибрагимова АН РТ), в 19861996 гг. - заведующий отделом рукописей и текстологии Института языка, литературы и искусств им. Г. Ибрагимова АН РТ. 
Nil Gafurovich Yuziev (1931-1996) was a linguist, Doctor of Philology, Professor, Honored Scholar of the TASSR (1981), Laureate of the G. Tukay State Prize of the Republic of Tatarstan (1974), literary critic, the author of 36 monographs and more than 300 articles. For more than forty years of his scientific activity, he pushed the boundaries of Tatar literary studies, suggesting new research approaches and concepts for evaluating national poetry. He made a great contribution to its development and created his own scientific school.

Nil Yuziev was born on January 10, 1931, in the village of Yamady, the Yanaulsky district of the Republic of Bashkortostan. After graduating from high school in his hometown in 1948, he moved to Kazan where he studied at the Department of Tatar Language and Literature of Kazan State University from 1948 to 1953. N. Yuziev, who always had a passion for science, completed his post-graduate course in 1953-1955.

While still in the graduate school, N. Yuziev combined literary criticism and scientific research: he published scientific articles in the republican media, was the head of the Department of Literary Criticism in the journal "Soviet Literature" (the current name "Kazan Utlary") from 1956 to 1960; later he held the position of executive secretary there. The young professional, who had just presented his Ph.D. thesis "Musa Jalil's Poems", was offered a position at the Department of Tatar Literature of Kazan State University in 1960, where he worked as an assistant and associate professor until 1975.

Alongside his pedagogical activities, N. Yuziev expanded the range of his scientific research. Taking twentieth-century Tatar poetry as his field of research, he sought new ways of analyzing poetry and organized his research on a conceptual basis. As a result, he presented his doctoral dissertation "Poetics of Tatar Soviet Poetry" in 1974. This same year, he was awarded the G. Tukay State Prize of the Republic of Tatarstan as the first literary critic for his books "The Harmony of Poetry" and "Modern Tatar Poetics".

N. Yuziev continued his research work at the G. Ibragimov Institute of Language, Literature and History of the USSR Academy of Sciences (Institute of Language, Literature and Arts of the Academy of Sciences of the Republic of Tatarstan) in 1975. He headed the Literary Sector of the institute from 1975 to 1985 , later on, he became the director of the Institute's Department of Manuscripts and
Textology and worked there from 1986 to his death. Under the supervision of N. Yuziev, six volumes of the history of Tatar literature were prepared and published, and the works of classical Tatar authors were issued as academic publications in more than 40 volumes. He was awarded the title of "Honored Scholar of the TASSR" in 1981 and was elected a corresponding member of the newly established Academy of Sciences of Tatarstan.

N. Yuziev, as a member of the Union of Writers of Tatarstan from 1961, took an active part in the socio-cultural life of the republic, was a member of the editorial board of "Kazan Utlary", made many speeches related to the development of poetry at Writers' Congresses, and supervised the work of a team, working on the Gabdulla Tukay Encyclopedia.

The scholar passed away on September $11^{\text {th }}$, 1996, in Kazan.

$\mathrm{N}$. Yuziev appeared in literary studies in the 1950s and proved himself to be a well-educated literary scholar and critic with a decent theoretical knowledge and innovative thinking. Scientific research of the scholar covers several areas: literary forms and genres as a single system; poetic structure and poetics; trends in the development of the twentieth century Tatar poetry; Tukay's oeuvre; creative laboratory and textologic activity of the scholar. These fields of research are interconnected but each of them requires specific methods of study. The fact that they are a part of a single scholar's activity is another proof that he was engaged in a wide range of scientific research.

The study of literary forms and genres as a single system was the focus of his scientific research: $\mathrm{N}$. Yuziev explored the patterns of change and development in prose, poetry and other related genres in his early works. His main concept and theoretical provisions for the study of literary forms and genres are based on themes and topics, the unity of feelings and thoughts, the qualities of the main characters, figurative thinking and characteristic features of style.

For instance, his monograph "Musa Jalil"s Poems" (1960, 1969) [Musa Жəlil poemalars], which was published as a summary of his Ph.D. thesis and was highly appreciated at the time, made $\mathrm{M}$. Jalil's poetry the focus of his study; it justified the development and evolution of the poem as a genre based on the poet's work and identified the innovations introduced in poetry by Jalil. In his collection of critical reviews "The Poetry of Life" (1961), N. Yuziev discussed the topics related to style, crea- 
tive identity and literary skills through the literature of S. Khakim, A. Faizi and others. His works "The Revival of Traditions: Etudes on Modern Tatar Poetry" (1966), "Beauty and Skill in Art: Critical Reviews" (1969) analyze the genre of the novel as an integrated system based on the novels of $\mathrm{G}$. Bashirov, M. Amirov, F. Husni, A. Rasikh, G. Akhunov, which became the object of his research. In these works, he suggested a different approach to studying Tatar literature: he proved that the study of the art of speech in conjunction with various sciences such as history, linguistics, art, cinema, painting and theatre could lead to unexpected results. N. Yuziev was known as a scholar who studied the poetry of the $20^{\text {th }}$ century as an entity, developing his own conception in his monographs "Treasures of Literature" (1978), "The World of Poetry" (1981) [Shigariat danyasa: ədəbi tənkyit məkalələre], "The World of the Poet: The Poetry of H. Taktash, M. Jalil, H. Tufan, S. Hakim" (1987) [Mir poeta: o tvorchestve Kh. Taktasha, M. Dzhalilia, Kh. Tufana, S. Khakima]. By analyzing the oeuvre of M. Gafuri, G. Taktash, F. Burnash, M. Jalil, H. Tufan, G. Afzal, S. Suleymanova, Sh. Galiev, R. Haris and other poets, N. Yuziev demonstrated that the literary works of the classics, who lived and worked in different eras, had an internal common ground and creative connection rooted in their national mindsets. He also proved that the literary and social processes, mentioned by Tukay in the early $20^{\text {th }}$ century, were not interrupted by the revolution, but kept developing. His series of publications proved that Tatar writers, although belonging to different art movements and political eras, were interconnected in terms of their work's content. In other words, the principle of continuity was at the core of his scientific research and criticism. N. Yuziev highlighted both traditions and novelty in Tatar poetry of the $20^{\text {th }}$ century when studying the poets' creative portraits, worldbuilding methods in their works, their ideological and aesthetic features, and the features of their imaginative thinking.

These works of the scholar are of conceptual significance and value in Tatar literary studies. Firstly, his monographs determined the state and course of national literary studies at that time, setting out internal laws and stages of the twentiethcentury Tatar poetry development. Secondly, they suggested new methods for the analysis and evaluation of literary works and new approaches to the studies of imaginative thinking internal mechanisms. Thirdly, they can be considered the first works in Tatar literary studies that have laid the foundation for the study of the writers' creative laboratory and have determined its theoretical substantiation.

Another trend of the scholar's scientific activity concerned theoretical issues of structuring poems and poetics. In his works "The Harmony of Poetry: Poetics in Tatar Verse" (1972) [Shigyr harmonyase: tatar shigyre poetics], "Modern Tatar Poetics: An Introduction to the Theory of Poetry" (1973) [Həzerge tatar poetikasy: poesiia teoriiasenə keresh], "Tatar Poetry: Critical Reviews" (1991) [Tatar shigyre: tənkyit məkalələre], $\mathrm{N}$. Yuziev focuses on the matter of tradition and novelty, poetic forms and content, the relationship between literature and other types of art, creative processes, the psychology of creativity, Tatar versification and the poetics of syllabic verse. In these works, the scholar emphasizes that poetry, along with the sensual element, should convey "complex, contradictory phenomena of the human spiritual state" [Iuziev, 1973, p. 204], paying more attention to poets' identity and political views; he highly elevates the role of philosophy in the poetry, following the literary conception of the era. By numerous examples he shows that the structure, poetics, unity of rhyme and rhythm are inseparable from thought and content in poetry. Emphasizing the significance of scientific and evidence-based research, the scholar shows the importance of using archival sources, poets' written materials and personal memoirs in the analysis of any author's literary skills and poetics of their works.

The third area of N. Yuziev's scientific research is his study of Tukay's works. In "Modern Tatar Poetics: An Introduction to the Theory of Poetry" (1973) [Həzerge tatar poetikasy: poesiia teoriiasenə keresh] he attempted to find new ways to study Tukay's legacy, emphasizing the need to improve the ways of studying the poet's oeuvre. In this regard, N. Yuziev noted that the work of the poet should be studied in a broad sense, i.e. through the prism of the literary and socio-cultural ideas of that period. The scientist opened a new field of study for himself in the early 1990s: he began exploring the written literary and cultural heritage including archival sources, genealogies of writers and manuscripts bringing them back to the public. On this path, the issue of Tukay was again raised in his scientific research. In the monograph "Tatar Poetry: Critical Reviews" (1991) [Tatar shigyre: tənkyit məkalələre] and numerous articles, he offered a new scientific interpretation of Tukay's literary works. In addition, he successfully sought to discover previously unpublished $\mathrm{G}$. 
Tukay's poems, unknown to a wide range of readers, and published them correcting old misconceptions along the way. He argued for the need to eliminate such errors and blank spaces, citing as an example the verses of M. Ukmay "If I Read the Quran" and N. Dumawi "The Quran".

Thus, Nil Yuziev created his School in Tatar literary studies, presenting conceptual ideas novel for that time. Therefore, the scholar's accomplishments are still paving the way for new literary studies, including the analysis and assessment of developmental and evolutionary features of twentieth-century Tatar poetry.

\section{References}

Iuziev, N. G. (1961).Tormysh poetryazyase: adəbi tankyit makalalare [Poetry of Life: Articles in Literary Criticism]. 160 p. Kazan, Tatar. kit. nəshr. (In Tatar)

Iuziev, N. G. (1966). Traditionlar yagarganda: khazerge Tatars poetryyase turnda etudlar [When Traditions are Renewed: Etudes on Modern Tatar Poetry]. 172 p. Kazan, Tatar. kit. nəshr. (In Tatar)

Iuziev, N. G. (1969). Musa Жəlil poemalars [Musa Jalil's Poems]. 135 p. Kazan, Tatar. kit. nəshr. (In Tatar)
Iuziev, N. G. (1969). Səngatchə maturlyk həm ostalyk: adabi tankyit məkalalare [Artistic Beauty and Skill: Articles in Literary Criticism]. 272 p. Kazan, Tatar. kit. nəshr. (In Tatar)

Iuziev, N. G. (1972). Shigyr harmonyase: tatar shigyre poetics [The Harmony of Poetry: Poetics of Tatar Poetry]. 220 p. Kazan, Kazan un-ty nəshr. (In Tatar)

Iuziev, N. G. (1973). Hozerge tatar poetikasy: poesiia teoriiasena keresh [Modern Tatar Poetics: An Introduction to the Theory of Poetry]. 351 p. Kazan, Tatar. kit. nəshr. (In Tatar)

Iuziev, N. G. (1981). Shigariat danyasa: adəbi tankyit makalalare [The World of Poetry: Articles in Literary Criticism]. 312 p. Kazan, Tatar. kit. nəshr. (In Tatar)

Iuziev, N. G. (1991). Tatar shigyre: tonkyit məkalalare [Tatar Poetry: Critical Reviews]. 303 p. Kazan, Tatar. kit. nəshr. (In Tatar)

Iuziev, N. G. (1987). Mir poeta: o tvorchestve Kh. Taktasha, M. Dzhalilia, Kh. Tufana, S. Khakima [The World of the Poet: On the Works of H. Taktash, M. Jalil, H. Tufan, S. Hakim]. 190 p. Kazan', Tatar. kn. izdvo. (In Russian)

Odiplarebez: Bibliografik beleshmalek: 2 tomda (2009) [Our Authors: Bibliographic Reference: In 2 Volumes]. Tom 2. Tez. R. N. Dautov, R. N. Rahmani. 735 p. Kazan, Tatar. kit. nəshr. (In Tatar)

\title{
НИЛ ГАФУР УЛЫ ЮЗИЕВНЕН ФӘННИ-ТӘНКЫЙДИ ЭШЧӘНЛЕГЕ
}

\author{
Нурфия Марс кызы Юсупова, \\ Казан федераль университеты, \\ Россия, 420008, Казан ш., Кремль ур., 18 нче йорт, \\ faikovich@mail.ru.
}

Нил Гафур улы Юзиев (1931 - 1996) әдәбият галиме, тәнкыйтьче, филология фәннәре докторы, профессор, ТАССРның атказанган фән эшлеклесе (1981), Татарстан Республикасының Г. Тукай исемендәге Дәүләт бүләге лауреаты (1974), 36 монография, 300 йөздән артык мәкаләләр авторы. Кырык елдан артык алып барылган фәнни эшчәнлегендә ул милли шигъриятне бәяләүнең яңа тикшеренү юлларын, концепциясен тәкъдим итеп, татар әдәбият белеме фәненең нәзари офыкларын киңәйтә, аны үстерүгә зур өлеш кертә, шушы юлда үзенең фәнни мәктәбен булдыра.

Нил Гафур улы Юзиев 1931 елның 10 гыйнварында Башкортстан Республикасының Яңавыл районы Ямады авылында дөньяга килә. Үзенең туган авылында гомуми урта мәктәпне тәмамлаганнан соң, 1948 елда Казанга килә һәм 1948-1953 елларда Казан дәүләт университетының татар теле һәм әдәбияты бүлегендә белем ала. Фәнгә омтылышы булган Н. Юзиев 19531955 елларда укуын аспирантурада дәвам итә.

Аспирантурада уку елларында ук Н. Юзиев тәнкыйди һәм фәнни эшчәнлекне бергә үреп алып китә: фәнни мәкаләләр, язмалар белән республикакүләм матбугат чараларында чыгышлар ясый, 1956-1960 елларда «Совет әдәбияты» (хәзерге «Казан утлары») журналында әдәби тәнкыйть бүлеге мөдире булып эшли, соңга таба жаваплы сәркатип вазифасын башкара. 1958 елда «Муса Жәлил поэмалары» дигән темага кандидатлык диссертациясе яклаган яшь белгеч 1960 елда Казан дәүләт университетының татар әдәбияты кафедрасына эшкә чакырыла, 1975 елга кадәр ул биредә ассистент, доцент булып эшли.

Педагогик эшчәнлек белән янәшәдә $\mathrm{H}$. Юзиев фәнни эзләнүләр спектрын да киңәйтә. Үзенең тикшеренү өлкәсе итеп XX гасыр татар поэзиясен алып, шигъриятне өйрәнүнең яңа 
юлларын эзли, тикшеренүләрен концептуаль нигездә оештыра башлый. Шуның нәтижәсе буларак 1974 елда «Татар совет поэзиясенең поэтикасы» дигән темага докторлык диссертациясен яклый. Шул ук елда «Шигырь гармониясе» hәм «Хәзерге татар поэтикасы» китаплары өчен, әдәбият галимнәреннән беренче буларак, Татарстан Республикасының Г. Тукай исемендәге Дәүләт премиясенә лаек була.

1975 елдан фәнни-тикшеренү эшләрен Н. Юзиев СССР Фәннәр академиясенең Казан филиалы Г. Ибраһимов исемендәге Тел, әдәбият һәм тарих институтында (1993 елдан Татарстан Республикасы Фәннәр академиясенең Г. Ибраһимов исемендәге Тел, әдәбият һәм сәнгать институты) дәвам итә, 1975-1985 елларда әдәбият секторын житәкли, ә 1986 елдан вафатына кадәр институтның кулъязмалар һәм текстология бүлеге мөдире булып эшли [Әдипләребез..., б. 695]. Н. Юзиев житәкчелегендә татар әдәбияты тарихының алты томлыгы әзерләнеп дөнья күрә, аның тырышлыгы нәтижәсендә классик татар әдипләре әсәрләренең 40 тан артык фәнни басмалары нәшер ителә. 1981 елда ул «ТАССРның атказанган фән эшлеклесе» исеменә лаек була, 1993 елда яңа оештырылган Татарстан Фәннәр академиясенең мөхбирәгъзасы итеп сайлана.

Н. Юзиев 1961 елда Татарстан Язучылар берлегенә кабул ителә һәм ул республиканың ижтимагый-мәдәни тормышындагы активлыгын тагын да арттыра: «Казан утлары» журналының редколлегиясе әгъзасы булып тора, Язучылар корылтайларында поэзия үсешен яктырткан чыгышлар ясый, ул житәкләгән төркем Тукай энциклопедиясен төзү эшен башлап жибәрә.

Галим 1996 елның 11 сентябрендә Казанда вафат була.

Н. Юзиев әдәбият белеменә узган гасырның илленче елларында килә һәм әдәби барышны өйрәнүгә караган фәнни язмалары, хезмәтләре белән үзен теоретик әзерлекле, белемле, яңача фикерләүгә омтылган әдәбият галиме, тәнкыйтьче итеп таныта. Галимнең фәнни эзләнүләре берничә юнәлешне колачлый: бербөтен нәзари система буларак әдәби төр һәм жанрлар проблемасы; шигырь төзелеше һәм поэтикасы мәсьәләләре; XX гасыр татар поэзиясенең үсеш-үзгәреш тенденцияләре; Тукай ижаты; әдипнең ижат лабораториясе, әдәбият чыганаклар белеме һәм текстология.
Бер-берсенә бәйле, әмма һәркайсы аерым эзләнү үзенчәлеген таләп иткән тармакларның бер шәхес эшчәнлегендә туплануы $\mathrm{H}$. Юзиевнең киң фәнни масштаблы галим булуын дәлилли.

Әдәби төр һәм жанр проблемаларын бербөтен система буларак өйрәнү аның фәнни эшчәнлегенең чишмә башында тора: беренче хезмәтләрендә үк Н. Юзиев проза һәм поэзиянең, аларга бәйле жанрларның үсешүзгәреш кануннарын өйрәнүгә керешә. Темапроблема, хис һәм фикер бердәмлеге, үзәк герой бирелеше, образлы фикерләү үзенчәлеге, стиль хасиятләре галим тарафыннан әдәби төрләрне һәм жанрларны, аларның үсешүзгәрешен өйрәнү юлында терәк төшенчәләр, нәзари нигез итеп куела.

Мисал өчен, кандидатлык диссертациясенең сөземтәсе буларак дөнья күргән һәм үз чорында ук югары бәяләнгән «Муса Жәлил поэмалары» (1960, 1969) монографиясендә ул, М. Жәлил ижатын өйрәнү үзәгенә алып, поэма жанрының үсеш-үзгәрешен, поэтик яңарышын аның ижаты мисалында дәлилли, шушы фонда поэзиягә шагыйрь алып килгән яңалыкларны төгәлләштереп бара. «Тормыш поэзиясе» (1961) исемле тәнкыйть мәкаләләре жыентыгында С. Хәким, Ә. Фәйзи һ.б. ижатларында шагыйранә стиль, ижади үзенчәлек, әдәби осталык проблемаларын тикшерә. «Традицияләр яңарганда: хәзерге татар поэзиясе турында этюдлар» (1966), «Сәнгатьчә матурлык һәм осталык: әдәби тәнкыйть мәкаләләре» (1969) хезмәтләрендә, Г. Бәширов, М. Әмир, Ф. Хөсни, А. Расих, Г. Ахунов романннарын тикшеру объекты итеп алып, роман жанрын бербөтен система буларак өйрәнә. Әлеге хезмәтләрдә ул татар әдәбиятын комплекслы тикшерү юлын тәкъдим итә: сүз сәнгатен төрле фәннәр - тарих, тел белеме, сәнгать, кино, рәсем һәм театр - белән тыгыз бәйләнештә өйрәнүнең, чиктәш эзләнүләрнең яңа нәтижәләргә алып килү мөмкинлеген исбатлый.

«Әдәбият хәзинәләре» (1978), «Шигърият дөньясы» (1981), «Мир поэта: о творчестве X. Такташа, М. Джалиля, Х. Туфана, С. Хакима» (1987) монографияләре белән Н. Юзиев ХХ гасыр шигъриятен бербөтен процесс буларак өйрәнгән, шушы юлда Ү3 концепциясен булдырган галим булып таныла. М. Гафури, h. Такташ, Ф. Бурнаш, М. Жәлил, Х. Туфан, Г. Афзал, С. Сөләйманова, Ш. Галиев, Р. Харис h.б. ижатларына заман нәзари югарылыгыннан бәя биреп, төрле чорларда яшәгән һәм ижат 
иткән классик әдипләр шигъриятен милли Үзенчәлекләргә нигезләнгән эчке уртаклык, ижади бәйләнеш тоташтыруын, XX йөз башында Тукай күтәргән әдәби һәм ижтимагый мәсьәләләрнең инкыйлаб белән өзелеп калмыйча, даими үстерелеп килүен дәлилли. Язмалар, эзлекле төстә, төрле юнәлешләрдә, сәяси дәверләрдә ижат иткән әдипләрнең мәгънәви жәһәттән бер-берсенә бәйләнгән булуын исбатлый, ягъни фәнни-тәнкыйди эзләнүләрнең нигезенә күчемлелек, дәвамлылык принцибы салына. Шагыйрьләрнең ижат портретларын, алар рухи мирасындагы дөнья сурәтен, идея-эстетик хасиятләрен, образлы фикерләү үзенчәлеген тикшерү аша Н. Юзиев XX гасыр татар поэзиясендәге традиция һәм яңачалыкны аерып чыгара.

Галим каләменнән төшкән бу юнәлештәге хезмәтләрнең татар әдәбият белемендә концептуаль әһәмияте, ү3 кыйммәте бар. Беренчедән, асылда милли әдәбият белеменең ул чордагы торышын һәм барыр юлын билгеләгән әлеге монографияләрдә XX гасыр татар шигъриятенең эчке кануннары, үсеш баскычлары билгеләнә. Икенчедән, әдәби әсәрне, әдәби ижатларны тикшерү-бәяләүнең, сурәтле фикерләүнең эчке механизмын өйрәнүнең Ү3 чоры өчен яңа, үзгә юллары тәкъдим ителә. Өченчедән, алар татар әдәбият белемендә әдипләрнең ижат лабораториясен өйрәнүне башлап жибәргән, шуның теоретик нигезләрен билгеләгән беренче хезмәтләрдән саналырга лаек.

Галим эшчәнлегендәге икенче тармакны шигырь төзелеше, шигырь поэтикасы кебек нәзари проблемалар тәшкил итә. «Шигырь гармониясе: татар шигыре поэтикасы» (1972), «Хәзерге татар поэтикасы: поэзия теориясенә кереш» (1973), «Татар шигыре: тәнкыйть мәкаләләре» (1991) хезмәтләрендә Н. Юзиев традиция һәм яңачалык, шигъри форма һәм эчтәлек, әдәбият һәм башка сәнгать төрләренең үзара бәйләнешләре, ижат процессы, ижат психологиясе, татар шигырь төзелеше һәм силлабик шигырь поэтикасы проблемаларын өйрәнә. Әлеге хезмәтләрендә галим, үз чоры әдәбият белеме алга куйган концептуаль нигездә, шигырьнең, хис-кичереш белән янәшәдә, «рухи халәтнең катлаулы, каршылыклы күренешләрен» [Юзиев, 1973, б. 204] житкерергә, шәхси башлангычка, ижтимагый күренешләргә игътибарны көчәйтергә тиешлеген ассызыклый, шигырь тукымасында фикер-фәлсәфәнең ролен югары күтәрә. Шигырь структурасының, поэтикасының, ритм-рифма берлегенең фикер, эчтәлек белән аерылгысыз бәйләнештә булуын күпсанлы мисаллар нигезендә дәлилли. Теләсә кайсы авторның әдәби осталыгын, әсәрләренең поэтикасын өйрәнү юлында фәнни, дәлилле тикшеренүләрнең мөһимлеген әйтеп, галим архив чыганакларына, шагыйрьләрнең $\mathrm{Y}^{3}$ фикерләренә, язмаларына, шәхси истәлекләренә таянуның әһәмиятен билгели.

Н. Юзиевнең фәнни эшчәнлегендәге өченче тармакны татар халык шагыйре Габдулла Тукай ижатын өйрәнү тәшкил итә. «Хәзерге татар поэтикасы: поэзия теориясенә кереш» (1973) хезмәтендә үк инде ул Тукай мирасын шәрехләүнең яңа юлларын эзли башлый, шагыйрь ижатын өйрәнү юлларын камилләштерү кирәклеген әйтеп чыга. Шуңа бәйләп, Н. Юзиев шагыйрь ижатының киң планда - шул чор әдәби барышы һәм ижтимагый-мәдәни фикере аспектында тикшерелергә тиешлеген белдерә.

Галим 1990 еллар башында үзе өчен яңа өлкәгә кереп китә: язма әдәби-мәдәни мирасны - архив чыганакларын, әдипләрнең шәжәрәләрен, кульязмаларны - өйрәнүгә һәм аларны киң катлам халыкка кайтару эшенә керешә. Шушы юлда аның гыйльми эшчәнлегендә кабат Тукай темасы калкулана. «Татар шигыре: тәнкыйть мәкаләләре» (1991) монографиясендә, күпсанлы мәкаләләрендә ул Тукай ижатына яңача фәнни интерпретация тәкъдим итә. Моннан тыш шагыйрьнең моңа кадәр басылмаган, киң катлам укучыга билгесез шигырьләрен эзләү һәм нәшер итү, шушы юлда элгәрге хаталарны төзәтү юнәлешендә дә нәтижәле эшчәнлек алып бара. М. Укмасыйның «Коръән укысам», Н. Думавиның «Коръән» шигырьләрен мисалга китереп, мондый ялгышларны, ак тапларны бетерергә кирәклекне дәлилли.

Димәк, Нил Юзиев татар әдәбият белемендә Y3 мәктәбен булдыра, Y3 чоры өчен яна, концептуаль фикерләрне яңгырата. Шуна да бүгенге әдәбият белемендә барган яңа эзләнүләрдә, XX гасыр татар шигъриятенең үсеш-үзгәреш үзенчәлеген өйрәнү-бәяләү барышында, поэтика, шигырь төзелеше өлкәләрендә галимнең хезмәтләре юл ярып бара.

\section{Әдәбият}

Әдипләребез: Биобиблиографик белешмәлек: 2 томда: Т. 2 / төз. Р. Н. Даутов, Р. Н. Рахмани. Казан: Татар. кит. нәшр., 2009. 735 б. 
Юзиев Н.Г. Тормыш поэзиясе: әдәби тәнкыйть мәкаләләре. Казан: Татар. кит. нәшр., 1961. 160 б.

Юзиев Н.Г. Традицияләр яңарганда: хәзерге татар поэзиясе турында этюдлар. Казан: Татар. кит. нәшр., 1966. 172 б.

Юзиев Н.Г. Муса Жәлил поэмалары. Казан: Татар. кит. нәшр., 1969. 135 б.

Юзиев Н.Г. Сәнгатьчә матурлык һәм осталык: әдәби тәнкыйть мәкаләләре. Казан: Татар. кит. нәшр., 1969. 272 б.

Юзиев Н.Г. Шигырь гармониясе: татар шигыре поэтикасы. Казан: Казан университеты нәшрияты, 1972. 220 б.
Юзиев Н.Г. Хәзерге татар поэтикасы: поэзия теориясенә кереш. Казан: Татар. кит. нәшр., 1973. 3516.

Юзиев Н.Г. Шигърият дөньясы: әдәби тәнкыйть мәкаләләре. Казан: Татар. кит. нәшр., 1981. 312 б.

Юзиев Н.Г. Татар шигыре: тәнкыйть мәкаләләре. Казан: Татар. кит. нәшр., 1991. 303 б.

Юзиев Н.Г. Мир поэта: о творчестве Х. Такташа, М. Джалиля, Х. Туфана, С. Хакима. Казань: Татар. кн. изд-во, 1987. 190 с. 